and replaced by a newly formed one." Caton (The Antelope and Deer of America, 2 d ed., New York, 188 I [?]) gives a lengthy description of the shedding process as observed by him upon antelope in captivity; also quotes Audubon and Bachman (Quadrupeds of America) as saying, "It was supposed by the hunters of Fort Union that the prong-horned antelope dropped its horns," - a supposition that these naturalists thought they had disproved by merely showing that it had an osseous horn-core. E. R. Alston (Biologia Centrali-Americana, I879-82, p. I I2, article “Mammalia”) says, "Although tke fact that the prong-buck sheds its horns annually was long well known to hunters and backwoodsmen, and had been noted by one or two writers, yet it was generally disbelieved or ignored by zoölogists ; and Mr. Bartlett, the observant superintendent of the Zoölogical Society's Gardens, was the first to demonstrate its truth and insist on its importance." Flower (Encyclopadia Britannica, 9th ed., p. 43I, article "Mammalia") says, "The only existing species [of the Bovida] in which such a process [shedding] occurs regularly and periodically is the American prong-buck (Antilocapra), in which the horns also differ from all others in being bifurcated."

This evidence resolves itself into three separate cases of direct observation on animals in captivity, - the statement by Audubon and Bachman of the belief of the hunters of Fort Union; and the indefinite statement of Mr. Alston, that " the fact that the prongbuck sheds its horns annually was long well known to hunters and backwoodsmen."

My own observations are as follows. I have several times handled skins of this animal from the Western plains, from which the horn-sheath could easily be drawn, exposing to view a partially formed horn beneath. These, I have every reason to believe, were wild animals. I think, at the least, I have examined six or eight such cases; also I have noticed many cases in which the hornsheath insensibly graded into skin, and was covered with hair for a considerable distance from its base, and many other cases where the demarcation was sharply drawn. Unfortunately I cannot recall at what seasons of the year these animals were killed. Again : in two or three cases have I known of taxidermists, uninformed that the phenomenon was known, coming to an independent conclusion that the antelope sheds its horns.

Now, let us see what the evidence amounts to. The generally accepted belief that confinement effects moultings must be taken into account; but, as far as I am aware, there is nothing in this evidence that would lend any support whatever to the idea that it could produce such a remarkable change as that of a permanently horned Cavicornia changing to a deciduous one. However, those antelope kept by Dr. Canfield and Judge Caton can hardly be strictly classed as animals in confinement. That of Dr. Canfield used to go hunting with him as far as twelve miles from home, we are told, and "hunted coyotes with tho dogs at night;" while those of Judge Caton had the run of a large park. Neither can a change of climate or natural food be called in to account for this moult as described by Dr. Canfield, for his buck was living in its native habitat.

The opinion of the hunters of Fort Union is of considerable value. While hunters, Indians, etc., are not good at distinguishing species, yet habits, when well marked, are usually much more familiar to them as a class than to naturalists.

My own observations on prepared skins also point very strongly toward the same conclusion. In no manner did these indicate an abnormal physical state. Those observed in the United States in captivity evidently were healthy; and so good an observer as $\mathrm{Mr}$. Bartlett would hardly have failed to have stated the fact if the specimen under his care was in poor health. That bucks killed in December and January all have short horns, grading insensibly into skin, and with base covered with hair, while those killed in the spring and summer months almost all have large horns, definitely marked off from the skin, can, I think, be explained in no other way than by an annual moult. That such is the almost universal belief of naturalists, my citations tend to show.

As the point is one of considerable interest, I have ventured to take up so much of your space, hoping thereby to call out some origin al observations from your readers.

Tacubaya, D.F., Mex., Jan. so.

\section{Felspar, or Feldspar?}

I HAVE read with interest the recent notes in Science, Nos. 305, 306 , and 309, on the orthography of "felspar" or "feldspar."

Whether the error consists in the omission or in the insertion of the $d$, seems doubtful. But apart from " national prejudice" in the matter, - which, if it exists elsewhere than in the imagination of your correspondent, "J. D. D.," is certainly to be deprecated, there are, it seems to me, good reasons for defending and adopting the British custom of spelling the word. These are based on probability, common sense, and, last, though not least, appropriateness.

It may, I think, if there is no proof to the contrary, be admitted that the name was originally given by a miner, or a mineralogist, and not by an agriculturist; and, if so, then it is in the highest degree improbable that either the miner or the mineralogist would associate this particular substance with the fields, with which it has no obvious connection, and it is in an equal degree probable that he would associate it with the rocks of which it is one of the chief constituents. In any case, the British custom of referring it to fels, or felsen (" a rock," "rockspar") is both sensible and appropriate, neither of which can be said of its reference to feld or felt (" a field," "fieldspar").

On these considerations alone, and not because of " national prejudice," or even custom, I consider it advisable to adhere to the spelling adopted by nearly all English geologists until some better reason than mere assertion, or the custom elsewhere, is advanced for not doing so.

Ottawa, Can., Jan. I4. Alfred R. C. SELWyN.

\section{The Soaring of Birds.}

Professor Pickering may possibly have the correct explanation of the soaring of birds; and, if so, will he be kind enough to explain it more strongly, so that the explanation may have the force of a demonstration in geometry? As it now stands, there appears to be'a fallacy somewhere.
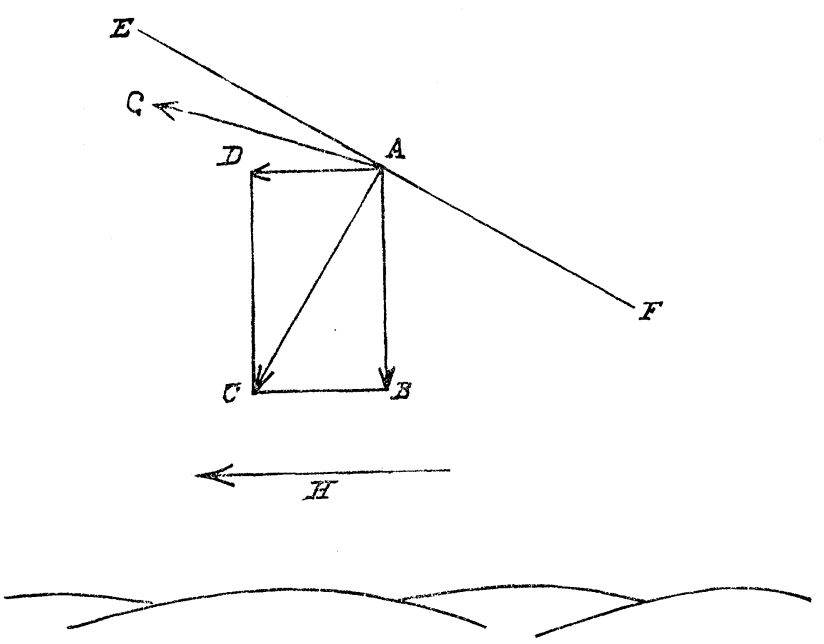

If the bird is acted on by two forces, $A B$ and $A D$, the resultant force would carry him to $C$; and he could by no means get to $G$ except by the action of a third force, which might be represented by a line drawn from $C$ to $G$. Professor Pickering makes no mention of any such third force, but without it how could the bird get to $G$ ?

Passaic, N.J., Jan. 12.

WM. KENT.

\section{The Color of Katydid.}

I OBSERVE in Science of Jan. I I mention of a pink katydid found by L. N. Johnson, Evanston, Ill. A large female specimen was found on my place at Wood's Holl, Mass., as early as I874, and sent to Professor Packard. Two others have been found at the same place, so that it would seem to be a defined species.

Boston, Mass., Jan. 2x. 